\title{
A rebuttal to Akabayashi and colleagues' criticisms of the iPSC stock project
}

\author{
Misao Fujita, ${ }^{1}$ Keiichi Tabuchi ${ }^{2}$
}

\begin{abstract}
In the October edition of the Journal of Medical Ethics, Akabayashi and colleagues state that 'to establish a heterogeneous [induced pluripotent stem cell] iPSC bank covering roughly $80 \%$ of Japan's population... the Japanese government decided to invest JPY110 billion (US\$ 1.1 billion) over 10 years in regenerative medicine research; a quarter of this was to be allocated to the iPSC stock project'. While they claim this amount of money to be an unfair distribution of state resources, we believe their assessment is based on a misunderstanding of the facts. Similarly, other criticisms by them are based on mistaken interpretations. This article is a rebuttal to the arguments that form the basis of Akabayashi and colleagues' five criticisms by explaining their misinterpretations.
\end{abstract}

\section{INTRODUCTION}

In the October edition of the Journal of Medical Ethics, Akabayashi and colleagues state that 'to establish a heterogeneous (induced pluripotent stem cell) iPSC bank covering roughly $80 \%$ of Japan's population...the Japanese government decided to invest JPY110 billion (US\$ 1.1 billion) over 10 years in regenerative medicine research; a quarter of this was to be allocated to the iPSC stock project. ${ }^{1}$ While they claim this amount of money to be an unfair distribution of state resources, we believe their assessment is based on a misunderstanding of the facts.

The official name of the iPSC bank project is the 'Core Center for iPS Cell Research' (herewith, 'iPSC stock project'). $^{2}$ Besides the construction and supply of clinical-grade iPSCs, as described by Akabayashi and colleagues, the project handles a wide number of

\footnotetext{
'Uehiro Research Division for iPS Cell Ethics, Center for iPS Cell Research and Application (CiRA), Kyoto University, Kyoto, Japan

${ }^{2}$ Medical Applications Promoting Office, Center for iPS Cell Research and Application (CiRA), Kyoto University, Kyoto, Japan
}

Correspondence to Dr Misao Fujita, Uehiro Research Division for iPS Cell Ethics, Center for iPS Cell Research and Application (CiRA), Kyoto University, Kyoto, 6068501, Japan; misao-fujita@cira.kyoto-u.ac.jp research and non-research projects. Thus, the budget is used for incidental projects, such as the development of basic technologies that are necessary to create and optimise methods for establishing, culturing and assessing iPSCs, research on the clinical-use of iPSC banks overseas, the acquisition and maintenance of intellectual property, and the dissemination of information about the stock. In other words, the amount being spent on building and supplying the iPSC stock is less than that cited by Akabayashi and colleagues.

Similarly, their other criticisms are based on mistaken interpretations. This article is a rebuttal to the arguments that form the basis of Akabayashi and colleagues' five criticisms by explaining their misinterpretations.

\section{MISUNDERSTANDINGS THAT ARE THE BASIS OF THE FIVE CRITICISMS}

First, they state that 'the popularity and surge of interest in iPSC research in Japan means that all studies conducting this kind of research are more attractive to funders' and cite problems with transparency in the decision making about the investment of state funds into the project. However, the funding decision did not deviate from standard protocol. Budgets executed by the Japanese government go through the following sequence: (1) Policy studies are carried out by an advisory group that includes outside experts. (2) Various ministries and agencies draw up draft budgets to implement these policies. (3) Requests submitted by the ministries and agencies are compiled into a draft budget by the Ministry of Finance. (4) The draft budget is deliberated and finally approved by a majority in the Diet (Japan Parliament). This process is open to the public, and the budget for the iPSC stock project was determined following this procedure. The authors provide no evidence justifying the claims that the budget was decided without objectivity or transparency.

Second, Akabayashi and colleagues state that the cell strains established by the iPSC stock project would only match the immunotypes of $30 \%-50 \%$ of the Japanese population, meaning that the remaining $50 \%-70 \%$ would not receive any direct benefits. They argue that it is unfair to use tax money to fund the project when only a proportion of the population benefits. However, it is not accurate to claim that the iPSC stock can only be used by patients with matching immunotypes. As with other human-derived materials, so long as donors provide consent, these high-quality, highly safe cells can be used in allotransplants in a larger number of patients. All cells in the iPSC stock are carefully screened and approved for human administration by regulatory authorities. The manufacturing facility is comparable with good manufacturing practice for investigational drugs. The technologies developed through this project can be extrapolated to other cellular therapies and also other research using iPSCs, such as drug development and disease modelling. When these points are taken into consideration, it is clear that even the proportion of the public whose cells do not have matching immunotypes will benefit from the iPSC stock project.

Third, Akabayashi and colleagues state that 'the government did not hold any public Q \& A session about the iPSC stock procedure'. However, the national project 'Research Center Network for Realisation of Regenerative Medicine', which includes the iPSC stock project, holds annual symposiums that are open to the general public. ${ }^{3}$ These symposiums regularly provide citizens with the opportunity to discuss with scientists state-funded research and how the research will benefit society. Moreover, the Center for iPS Cell Research and Application (CiRA), Kyoto University, disseminates information to the general public through its website, informational bulletins and public symposiums. ${ }^{4}$ Therefore, the claim by Akabayashi and colleagues that procedural justice was not granted is questionable.

Fourth, Akabayashi and colleagues claim that 'strong support of a particular project lessens a nation's capacity to address other intractable, serious illnesses, such as cancer or cerebrovascular disease'. However, of the other intractable, serious illnesses they listed, budget allocations for cancer research were nearly unchanged during the launch of the iPSC stock project. ${ }^{5} 6$ Further, budgets for policies and projects undergo annual, multilayered reviews that assess their progress, suitability of the budgets and other aspects. A 
framework is available for conducting the necessary reviews if a funded project does not produce expected results, if the societal conditions change or if another field more deserving of funding appears. In fact, the iPSC stock project is slated to be part of an overall policy review by the Ministry of Education, Culture Sports, Science, and Technology in 2020. There is already a system in place for periodic review to ensure that funding for a particular project does not decrease a nation's capacity to address other fields.

Fifth and finally, Akabayashi and colleagues argue that the disease-specific iPSC bank run by RIKEN (Japan) would be a better use of public funds for developing drugs for rare intractable diseases than CiRA's iPSC stock project. Although this is a valid point, the cells created by the iPSC stock project are expected to impact a wide range of research beyond clinical cellular therapies or drug discovery for rare intractable diseases. Referencing two recent studies, ${ }^{7}$ Akabayashi and colleagues state that 'between half and two-thirds of projects have not matched human leukocyte antigen (HLA) types' and 'if the demand for HLA matching is decreased, then the value of the iPSC stock bank will drop as well'. As explained in our rebuttal to argument 2, the use of the cells established by the iPSC stock project will have high value even if these premises are true. The iPSC stock contains highquality cells and excellent management facilities, and preparations with an eye to future market developments are currently under way. While the concerns raised by Akabayashi and colleagues are valid, they are debatable, and our position is that the social benefits of the iPSC

stock project remains strong regardless of the RIKEN bank.

\section{CONCLUSION}

Good ethics begin with good facts. This is the mantra of the Hastings Center. The value of the iPSC stock project is debatable, with some, like Akabayashi and colleagues, arguing that the social benefits do not justify the costs. However, to have a healthy debate on this topic requires an accurate assessment of the facts. As we argue here, many of the points by the opposition ignore the much broader scope of the iPSC stock project, and thus unfairly bring doubt into the project's value.

Acknowledgements The authors thank Dr. Tadaaki Hanatani, Ms. Naoko Takasu and Dr. Peter Karagiannis at the CiRA, Kyoto University for their technical support for the manuscript.

Contributors MF: conceptualisation, writing original draft and editing. KT: writing original draft and editing.

Funding Supported in part by the Uehiro Foundation on Ethics and Education.

Competing interests The opinions expressed in this paper are the authors' own and do not represent those of the CiRA of Kyoto University.

Patient consent Not required.

Provenance and peer review Not commissioned; internally peer reviewed.

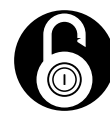

\section{OPEN ACCESS}

Open access This is an open access article distributed in accordance with the Creative Commons Attribution Non Commercial (CC BY-NC 4.0) license, which permits others to distribute, remix, adapt, build upon this work non-commercially, and license their derivative works on different terms, provided the original work is properly cited, appropriate credit is given, any changes made indicated, and the use is non-commercial. See: http:// creativecommons.org/licenses/by-nc/4.0/.

(c) Author(s) (or their employer(s)) 2019. Re-use permitted under CC BY-NC. No commercial re-use. See rights and permissions. Published by BMJ.

Check for updates

To cite Fujita M, Tabuchi K. J Med Ethics 2019;45:476-477.

Received 7 November 2018

Revised 19 December 2018

Accepted 21 December 2018

Published Online First 11 January 2019

\section{(P) Linked}

http://dx.doi.org/10.1136/medethics-2018-105333

$J$ Med Ethics 2019;45:476-477.

doi:10.1136/medethics-2018-105248

\section{REFERENCES}

1 Akabayashi A, Nakazawa E, Jecker NS. Endangerment of the iPSC stock project in Japan: on the ethics of public funding policies. J Med Ethics 2018;44:700-2.

2 Japan Science and Technology Agency (IST). Core Center for iPS Cell Research. https://www.jst.go.jp/saisei-nw/ en/research/core/index.html (Accessed 5 Nov 2018).

3 Japan Agency for Medical Research and Development (AMED). Public symposium of AMED for regenerative medicine. (in Japanese). 2017. https://www.amed.go. jp/news/event/RMsympo2017.html (Accessed 5 Nov 2018).

4 Center for iPS Cell Research and Application (CiRA). http://www.cira.kyoto-u.ac.jp/e/ (Accessed 5 Nov 2018).

5 Ministry of Education, Culture, Sports, Science and Technology (MEXT). Main Budget Item for FY2012, P.27. (in Japanese). 2012. http://www.mext.go.jp/ component/b_menu/other/_icsFiles/afieldfile/2012/02/ 07/1314488_19.pdf (Accessed 5 Nov 2018).

6 Ministry of Education, Culture, Sports, Science and Technology (MEXT). Main Budget Item for FY2013, P.31. (in Japanese). 2013. http://www.mext.go.jp/ component/b_menu/other/_icsFiles/afieldfile/2013/02/ 05/1330426_03.pdf

7 Asahi Digital Newspaper. iPSC: Many researches which do not match HLA patterns. 2018 (in Japanese). 2018. https://digital.asahi.com/articles/ ASL667KNRL66UBQU00P.html?rm=506 (Accessed 5 Nov 2018). 